\title{
Vertigem mediática nos megaeventos musicais
}

\author{
Malena Segura Contrera e Marcela Moro
}

\section{Resumo}

0 artigo propõe uma reflexão sobre a presença do amplo aparato mediático que promove a vertigem presente nos megaeventos musicais. Esse aparato mediático gera uma profusão de imagens visuais e auditivas fragmentadas e em constante e intenso movimento, caracterizando uma ambiência própria dos megaeventos. 0 texto se ocupa de compreender melhor a natureza "mega" desses eventos próprios da cultura urbana, bem como a enorme sedução que esse caráter superlativo exerce no público jovem que vai à busca exatamente dessa concentração massiva de pessoas em um mesmo espaço e dos excessos característicos dessa situação social.

\section{Palavras-chave}

Processos mediáticos. Megaeventos musicais. Vertigem. Cultura juvenil.

Malena Segura Contrera I malenacontrera@uol.com.br Doutora em Comunicação e Semiótica pela Pontifícia Universidade Católica de São Paulo - PUC-SP. Professora do Programa de Mestrado em Comunicação e Cultura Midiática da Universidade Paulista - UNIP.

Marcela Moro I marcela.moro@planconsultoria.com Mestre em Comunicação pela UNIP. Professora do Curso de Turismo da UNIP.

\section{Ambiência urbana e megaeventos}

As festas, as comemorações, os eventos, os rituais, as celebrações sempre estiveram presentes na cultura humana. Essas atividades são utilizadas e apropriadas com diferentes funções e conotações nos mais diferentes e distantes grupos, nos quatro cantos do globo, e 0 fato de se repetirem em culturas tão díspares e tão geograficamente remotas é um dos fatores que convertem os eventos em um elemento cultural de grande relevância.

Entender toda a complexidade desses elementos na cultura, bem como sua importância, no entanto, nos exigiria uma abordagem teórica muito ampla, que não figura como proposta deste artigo. Pretendemos apenas propor uma reflexão sobre a presença de elementos que promovem a vertigem possibilitada pelo amplo aparato mediático presente nos megaeventos musicais. Esse amplo aparato promove uma avalanche de imagens visuais e auditivas fragmentadas e em constante e intenso movimento.

Analisar os megaeventos musicais, no entanto, não se desvincula de uma discussão da sua 
evolução, visto que são produtos culturais ainda pouco pesquisados na área de Comunicação, mas que indubitavelmente possuem grande importância pelo enorme número de pessoas que mobilizam e arregimentam. Atualmente, eventos como Skol Beats, Coca-cola Vibe Zone, Nokia Trends e as mais diversas raves ou mesmo shows como U2, Rolling Stones, entre tantos outros, têm movimentado milhões de pessoas a cada edição aqui no Brasil.

A primeira questão que se propõe, portanto, é questionar o porquê dos eventos terem assumido o formato "mega", em especial considerandose que essa denominação "mega" é utilizada como um recurso até mesmo publicitário de sedução do público para esse contexto (tornado contemporaneamente atraente) de concentração massiva de pessoas em um mesmo espaço. ${ }^{1}$

Eventos, como dito anteriormente, sempre existiram, desde os rituais mais primitivos, considerando as festas, as celebrações, entre tantas outras manifestações que têm como característica básica o padrão de evento. De acordo com Ilka Paulete Svissero Tenan (2002, p.13), eventos podem ser definidos como acontecimentos especiais, antecipadamente planejados e organizados, que reúnem pessoas com interesses comuns.
Sempre presentes na história da humanidade, no entanto, os eventos somente têm sua estrutura e, principalmente, intensidade modificada, tal como apresentado no formato "mega", no contexto da cultura de massas e à estética por esta imposta, característica do século XX, que altera não somente as relações espaço-temporais e as estruturas de vivência do homem, que migra do rural para 0 urbano, mas, principalmente, sua percepção do mundo.

\begin{abstract}
A Modernidade designa uma grande quantidade de mudanças tecnológicas e sociais que tomaram forma nos últimos dois séculos e alcançaram um volume crítico perto do fim do século XIX: industrialização, urbanização e crescimento populacional rápidos; proliferação de novas tecnologias e meios de transporte; saturação do capitalismo avançado; explosão de uma cultura de consumo de massa e assim por diante. (SINGER, 2004, p. 115)
\end{abstract}

Instaura-se o pensamento moderno e com ele 0 choque da Modernidade e 0 aumento radical das estimulações nervosas em meio a um cotidiano repleto de urgências, intensidades, sobrecarga sensorial, desorientação, fragmentação, mergulho nos sinais e imagens; em resumo, em meio ao hiperestímulo da nova dinâmica da vida humana urbana, permeada pela velocidade associada à multiplicação desenfreada dos contatos mediatizados. 
George Simmel, citado por Ben Singer (2004, p. 116), diz que:

0 rápido agrupamento de imagens em mudança, a descontinuidade acentuada ao alcance de um simples olhar e a imprevisibilidade de impressões impetuosas: essas são as condições psicológicas criadas pela metrópole. A cada cruzar de rua, com o ritmo e a multiplicidade da vida econômica, ocupacional e social, a cidade cria um contraste profundo com a cidade pequena e a vida rural.

Todo este conjunto de mudanças, todo este hiperestímulo, como aponta Singer, alteram, sem sombra de dúvidas, a experiência e a percepção da vida do homem.

A cidade moderna parece ter transformado a experiência subjetiva não apenas quanto ao seu impacto visual e auditivo, mas também quanto às suas tensões viscerais e suas cargas de ansiedade. A experiência moderna envolveu um acionamento constante dos reflexos e impulsos nervosos que fluíam pelo corpo 'como energia de uma bateria', tal como descreveu Benjamin. (SINGER, 2004, p. 127)

É o hiperestímulo como a nova ambiência do homem moderno.

0 megaevento é produto da modernidade, é produto da cultura de massas e só poderia se arquitetar como tal em meio à nova percepção e experiência do moderno, que se concebe, em especial, no início do século XX. Enquanto os antigos rituais e festas caracterizavam-se pela sua ocorrência em meio à comunidade, em meio às aldeias, tribos ou diferentes grupos que se constituíam como base para a sociedade arcaica, o Megaevento, o espetáculo de massa, tem como cenário a cidade moderna e, principalmente, como berço de nascimento - a metrópole e, posteriormente, a megalópole. 0 megaevento vem compor o espetáculo urbano.

A tecnologização da vida do homem passa a ser amparada, pautada e construída junto ao desenvolvimento dos media, media estes vistos no seu aspecto funcional de servir como novos suportes da informação e também como promotores da cultura de massas. De mediadores, os media passam a invadir o espaço privado deste homem; essa invasão e onipresença são elementos fundamentais para 0 entendimento da contemporaneidade e do cenário do surgimento dos megaeventos.

Na mesma medida em que esses fenômenos afastam o homem da experiência do sagrado, que é presencial e pressupõe a co-participação direta, constituem esta nova forma de percepção do mundo, percepção esta da velocidade, da informação, da eletricidade, do contexto moderno e da formatação de uma cultura pensada para mobilizar comportamentos de massa.

W. Benjamin (1997, p. 175) interpreta este contexto com base em uma interessante metáfora:

A metrópole e a esteira rolante sujeitaram os sentidos humanos a um tipo complexo de treinamento. 0 organismo mudou de marcha sincronizando-se ao mundo acelerado. Esse condicionamento acabou por gerar uma necessidade nova e urgente de estímulos, uma vez que somente passatempos estimulantes podiam corresponder às energias nervosas de um aparelho sensório calibrado para a vida moderna. 
Dessa forma, tal como aponta Benjamin, traçando um paralelismo elucidativo entre a esteira rolante e a vida moderna, essa nova vivência tecnologizada altera de forma profunda a forma deste homem de perceber 0 mundo, e, como um dos resultados deste novo processo, cria-se a necessidade de passatempos estimulantes, parafraseando Benjamin, capazes de corresponder às energias nervosas desse indivíduo moderno; a ampliação e a nova intensidade dos eventos são concebidas também como resposta a este processo.

0 megaevento, assim, responde à nova lógica da cultura de massas do século XX e à herança dromológica que dela herdamos, na qual a percepção do homem encontra-se alterada em função da própria velocidade contemporânea, da vida urbana e da quase onipresença dos media. Esse tipo de evento nasce, dessa forma, em consonância e como resposta à essa ambiência na qual o hiperestímulo e a intensidade são recursos necessários para que esse homem, anestesiado, reaja de alguma forma à estimulação a qual está submetido pelos media eletrônicos diariamente.

\section{Do hiperestímulo à anestesia}

A lógica da modernidade é a lógica da velocidade. Velocidade de acontecimentos, de informação, de deslocamentos. É a lógica do estímulo sensorial ininterrupto, veloz e excessivo.

Sobre esse estigma da velocidade e sobre sua ampla influência no modo de vida contemporâneo,
Paul Virillio, que se ocupa especialmente dos estudos em dromologia, diz que:

Com a realização de um progresso do tipo dromocrático, a humanidade vai deixar de ser plural. Para cair na situação de fato, ela tenderá a se cindir exclusivamente em povos esperançosos (a quem é permitido esperar pelo amanhã, pelo futuro: a velocidade que eles capitalizam dando-Ihes acesso ao possível, isto é, ao projeto, à decisão, ao infinito - a velocidade é a esperança do Ocidente). E povos desesperançosos, imobilizados pela inferioridade de seus veículos técnicos, vivendo e subsistindo num mundo finito. (VIRILIO, 1996, p. 57)

Aos "povos desesperançosos" dos países de maioria pobre, como o Brasil, que vêem a tecnologia das máquinas domésticas de velocidade chegarem até eles com quase uma década de atraso (e a preços ainda assim absurdos), resta a busca do futuro (e da vertigem da velocidade) nos grandes espaços sociais financiados por grandes empresas e grandes verbas, que ofertam essa experiência da velocidade como quem oferece uma amostra dos futuros paraísos artificiais.

Esse, é claro, é o caso dos media que, por sua vez, ocupam papel fundamental nesse contexto, visto que se colocam como elementos viabilizadores desse imenso aparato tecnológico que oferecem novos tipos de contato em meio à hiperestimulação constante do ambiente urbano contemporâneo.

Outdoors, backligths, placas, faixas, muros e toda e qualquer edificação que compõe 0 ambiente 
urbano converte-se em suporte mediático, suporte de informações e, principalmente, de publicidade. Meios de transporte e os próprios veículos de som, ambos nas velocidades características das grandes cidades, terminam por constituir 0 ambiente urbano moderno, ou o cenário moderno das grandes cidades, complementado por todos os apelos visuais dos media eletrônicos, que se multiplicam pelas áreas urbanas.

É o cenário do hiperestímulo materializado. Por todos os lados cores, sons, imagens, fotografias, textos, frases, apelos, chamarizes, numa ininterrupta disputa pela atenção do indivíduo que circula por esse ambiente enlouquecido.

Georg Simmel insistiu que o estímulo sensorial excessivo, tal como 0 associado às pressões da vida urbana, tinha 0 efeito fundamental de exaurir ou incapacitar os sentidos. "A idéia era que os nervos humanos eram sujeitados ao desgaste físico. [...] Nervos superexcitados e esgotados criaram um modo de percepção fatigada ou blasé que imaginava 0 mundo em um tom uniformemente insípido e cinzento." (SIMMEL apud SINGER, 2004, p. 140). Simmel e outros estudiosos da neurastenia da vida moderna procuraram comprovar que o hiperestímulo a que 0 indivíduo que circula nas cidades está submetido é tão grande (e ainda maior na contemporaneidade) que, como forma de defesa, o mesmo passa a um estado de baixa percepção desses estímulos, a uma visão fatigada do mundo - a uma visão anestesiada deste dia-a-dia.
0 homem contemporâneo encontra-se anestesiado. Em outro texto (CONTRERA, 2002, p. 64), chamamos a atenção para o fato de que a origem etimológica da palavra "anestesia" provém da palavra grega, aisthétikos, "suscetível à percepção pelos sentidos", tendo recebido 0 prefixo de privação, ou seja, significando a não percepção pelos sentidos.

A lógica da vida contemporânea, baseada nas grandes cidades, nas massas e na convivência tão próxima homem-a-homem, além da sua total imersão no universo mediático, que torna tão intenso seu dia-a-dia, fez com que este homem, como forma de se defender de uma dinâmica tão invasiva, tão permeada e baseada pelo hiperestímulo contínuo e ininterrupto, desenvolvesse como defesa ou fuga deste processo um estado anestésico perante a enorme quantidade de estímulos, das mais diferentes naturezas, aos quais está diariamente exposto.

A sensibilidade estética e ética encontram-se nitidamente conexas uma na outra e os indivíduos que tem de viver sob estas condições há pouco mencionadas sofrem de uma atrofia de ambas. A beleza da natureza e a beleza do ambiente cultural, fruto da acção humana são absolutamente necessárias para a saúde moral e espiritual do homem. A total cegueira de alma para tudo o que é belo, agora a alastrar-se rapidamente por toda a parte, constituí-se uma enfermidade do espírito, que deveria ser abordada seriamente, por que vai de mão dada com a insensibilidade em relação a tudo o que é repreensível sob o ponto de vista ético. (LORENZ, 1992, p. 30-31) 
0 homem moderno está anestesiado, está imunizado para conseguir viver dentro da lógica de uma cultura que serve a infinitas formas da propagação do capitalismo, via consumo, e que o submete a uma quantidade de estímulos sensoriais nunca antes verificada na história.

\section{Da anestesia a uma nova produção de "super-hiperestímulos" - os megaeventos}

Estamos imersos em hiperestímulos e, como estratégia adaptativa, nos anestesiamos.

Anestesiamo-nos porque certamente é uma estratégia mais econômica, ou seja, que exige menos esforço adaptativo do que lidar com a crise trazida pela contemporaneidade no equilíbrio da economia do prazer-desprazer² ${ }^{2} 0$ homem urbano contemporâne $0^{3}$ encontra-se em um estado de conforto absoluto, de um lado, mas é, por outro lado, hiper-estimulado o tempo todo pela ambiência contemporânea, na qual a mídia marca absoluta presença. Há um crescente acomodamento muscular, acompanhado de uma exaustão sensorial. Uma das conseqüências seria o tédio mortal, conforme aponta K. Lorenz (1992).

Nesse redemoinho sensorial, mais fácil do que lidar com a dinâmica do contato ininterrupto com um enorme número de outros indivíduos com os quais não possuímos qualquer vínculo, é tornarmo-nos imunes, indiferentes aos apelos do outro.

Estabelecido esse quadro, o mercado vê, nessa defesa quase letárgica do homem, a necessidade da criação de estratégias para que os contatos comunicativos continuem existindo - mesmo que esses contatos, de fato, se constituam em formas de incomunicaçãa $0^{4}$. A estratégia é, então, aumentar gradativamente 0 estímulo.

Do hiperestímulo de Singer passamos aos super-hiperestímulos (a hipérbole é proposital) promovidos pela mídia e inseridos no contexto das mais variadas atividades, dentre as quais se destacam exemplarmente os megaeventos.

Os megaeventos contemporâneos, com seus milhares de participantes, são resultado da evolução das cidades, da evolução do moderno, do contexto criado e da lógica contemporânea, de seu modo de vida, da incomunicação gerada por elas. Para atender ao aumento vertiginoso da população e à sua concentração em pequenos espaços, somente a estruturação de eventos atrativos de lazer amplificados seria suficiente para a criação de modelos de espaços públicos de convivência coletiva semelhantes à lógica

A economia do prazer-desprazer foi apresentada por Konrad Lorenz, no livro Os oito pecados mortais da civilização, e trata de que "toda a aprendizagem de um comportamento, seguida de recompensa, leva o organismo a aceitar situações penosas no presente em vista do prazer futuro". (LORENZ, 1992, p. 38)

Usamos aqui o termo "homem urbano contemporâneo" para tratar mais especificamente do grupo humano que está efetivamente envolvido pelo aparato mediático, ou seja, o homem ligado à técnica, com recursos econômicos e estabilidade social mínima para envolver-se com 0 aparato mediático. Certamente isso não se aplica aos refugiados, aos sem-terra, ao grande número de miseráveis que enfrentam condições de vida sub-humanas pelo mundo afora.

Para uma reflexão sobre o fenômeno da incomunicação, remetemos ao livro Os meios da incomunicação (BAITELL0 JR., 2005a). 
urbana, à lógica moderna. Os megaeventos são emblemáticos desse ambiente urbano e da experiência contemporânea proposta como novo padrão para esse - também novo ambiente.

Concentrações cada vez maiores de sensações visuais e auditivas traduzem a intensidade das novas atividades, que demonstram a tendência encontrada em todos os meios de comunicação de massa, bem como nas mais diversas atividades do homem, como esportes de aventura, entre outras, e que podem ser traduzidas na nova tendência de eventos de curta duração, velozes, fortes e saturados de emoção. Extravagância nas produções, motivos burlescos - que às vezes retomam a estética do grotesco - e apresentações ruidosas adquirem maior proeminência nessa nova dinâmica que insere ainda a presença massiva da tecnologia. Nesse novo universo circense, a técnica é adorada como o fetiche máximo, sinônimo de atualidade, e incorporada de forma visceral tanto no formato do megaevento, quanto pelo público que o freqüenta.

Somente 0 hiperestímulo mediático não é mais suficiente para gerar qualquer estímulo no homem - para tirá-lo da anestesia. Superhiperestímulos são necessários para tentar uma reação menos letárgica e mais participativa desse homem contemporâneo.
Para 0 senso comum, um corpo anestesiado é aquele corpo privado total ou parcialmente da sensibilidade. É o corpo sem sensações, cuja incitação depende de elevados graus de estímulo para que se consiga algum resultado - alguma sensibilização perante qualquer estimulação e que, em alguns casos, continua ainda sem responder a tais estímulos. "Sensações cada vez mais fortes são necessárias para penetrar os sentidos atenuados, para formar uma impressão e re-despertar uma percepção". (SINGER, 2004, p. 140)

É com base nessa lógica que os media contemporâneos agem. É também com base nessa lógica que os megaeventos musicais constituem seu formato, permeados pelo aparato mediático, especialmente 0 eletrônico, tanto em sua divulgação quanto, principalmente, em sua estrutura de realização, invadida pelos apelos publicitários, pelos telões, faixas, backlights, pelo laser, pela iluminação intensa, pela extravagância; uma quase insanidade materializada em sua programação e sua estrutura, recriando ambiências que remetem claramente a algumas práticas que buscam os estados alterados da consciência.

É explicitamente 0 caso das famosas raves ${ }^{5}$, em que a música eletrônica marca os ritmos, os softwares comandam as imagens, e a batida

Cláudio Manuel Duarte Souza (documento eletrônico): "a rave trata-se de uma festa, durante toda a noite, aberta ao público em geral, onde a música tecno é tocada em alto som e muitas pessoas consomem diferentes "químicos", embora isso não seja obrigatório. [...] Numa Rave, o dj é um xamã, um pregador, um chanceler da energia - eles controlam as "viagens" dos dançarinos através de sua especial escolha musical e de sua habilidade de manipular a música. Uma boa parte do conceito de rave é fundamentada no sobrecarrego de sensoriedade de áudio e de um grande estímulo visual que, juntos, elevam as pessoas a um estado existencial físico e psicologicamente alterado". 
repetitiva dos sons leva os participantes a uma pseudo-transcendência, definida, em vários eventos, como é o caso dos psy trances, como seu objetivo:

Ele criou a conexão entre batidas eletrônicas, espiritualidade, yoga e música com o seu conceito de "redefinir 0 antigo ritual tribal para 0 século XXI", guiando o público através do trance a um estado de consciência mais elevado 6 . (Disponivel em: <http://www.newagepunk.com/ tranzine/13/historia_psy_trance.html> Acesso em: 31 ago. 2006)

Retomam-se, nesses formatos, os modelos dos antigos rituais, adequando suas características aos recursos e gostos contemporâneos da música, das batidas, da repetição imitando os antigos cânticos tribais, a busca do êxtase por meio da nova estética contemporânea.

Esses formatos intensos, vertiginosos e

mediatizados eletronicamente nos levam a um segundo traço constitutivo dos megaeventos contemporâneos, para além do primeiro aspecto apresentado ( 0 caráter "mega"): sua característica vertiginosa, de uma vertigem - provocada pelo espaço ou quimicamente provocada - presente em especial a partir de meados do século XX. Na década de 60 , mais especificamente em 1969 com Woodstock ${ }^{7}$, já podíamos perceber alguns traços característicos desse processo.

\section{Da sensorialidade e do tempo lento à vertigem midiática}

Norval Baitello Jr. (documento eletrônico), em seu artigo "0 Tempo Lento e o Espaço Nulo" pontua que o meio primário ${ }^{8}$, em sua natureza corporal concreta, é por excelência a mídia da sensorialidade, da vivência, da proximidade e que, juntamente com o meio impresso, são caracterizados por uma temporalidade mais lenta, uma vez que o tipo de mediação que ocorre nos dois casos permite a reflexão e a retrospecção.

Os pequenos eventos, os rituais, as festas, as celebrações de pequeno porte podiam ser considerados como situações de mediação primária e secundária, já que se caracterizavam pela presença física, pela participação direta, pela vivência pessoal, pelo uso de vestimentas e

Descrição do novo tipo de música e evento chamado de Psy Trance, com origem da Índia e que se espalhou rapidamente pelos quatro cantos do globo, tomando o formato de muitas raves e que demonstra claramente a retomada do formato ritual, sua readaptação e o objetivo de um estado de consciência diferenciado (KANDLE [documento eletrônico]).

Ocorrido em agosto de 1969 em uma fazenda na cidade de Bethel, estado de Nova lorque, Woodstock é considerado até hoje o mais importante festival de música já ocorrido. 0 evento, inicialmente planejado para 50 mil participantes, acabou alcançando quase 500 mil pessoas que criaram, neste local, um universo paralelo ligado a contracultura tão latente neste momento histórico.

Harry Pross, citado no artigo supramencionado, propõe uma classificação bastante simples para os sistemas de mediação, como afirma N. Baitello. Pross pontua que a mídia pode ser classificada como mídia primária - aquela que pressupõe a presença física na relação entre emissor e receptor -; mídia secundária - "aqueles meios de comunicação que transportam a mensagem ao receptor, sem que este necessite de um aparato para captar seu significado", como o caso dos textos escritos; e mídia terciária - como "aqueles meios de comunicação que não podem funcionar sem aparelhos tanto do lado do emissor quanto do lado do receptor" (PROSS apud BAITELLO JR, [documento eletrônico]). 
pinturas corporais específicas e pelo tempo lento da reflexão e/ou da retrospecção, ou seja, pela ancoragem na experiência sensório-motora. Nesses eventos/rituais, a presença física e a participação direta nos rumos do próprio acontecimento garantiam a preservação da dimensão sagrada do evento, na qual o grupo resgatava o sentido de religiosidade (religare), ou seja, de realidade comum, como aponta Vilém Flusser:

[...] "senso de realidade" é, sob certos aspectos, sinônimo de 'religiosidade'. Real é aquilo no qual acreditamos. Durante a época pré-cristã o real era a natureza, e as religiões pré-cristãs acreditam nas forças da natureza que divinizam. Durante a Idade Média o real era o transcendente, que é o Deus do cristianismo. Mas a partir do século XV o real se problematiza. A natureza é posta em dúvida, e perde-se a fé no transcendente. Com efeito, nossa situação é caracterizada pela sensação do irreal e pela procura de um senso novo de realidade. Portanto, pela procura de uma nova religiosidade. (FLUSSER, 2002, p. 13)

Nesse caso, as experiências de vertigem faziam parte de práticas de resgate de uma religiosidade original, e aconteciam em um contexto religioso, apontando para a busca de transcendência dos estados ordinários da consciência, como experiência de resgate de um sentido cósmico, que remetia sempre aos mitos cosmogônicos, agindo assim como uma experiência re-criadora.

Esgarçado esse sentido de religiosidade e, portanto, de realidade, surgem os comportamentos de busca pelas novas formas de vivenciar essa religiosidade, procurando pelo resgate de uma realidade que faça sentido.

Os megaeventos perdem essas características dos rituais originais e se inserem nessas novas formas de busca. Por concentrarem um enorme número de pessoas - tal como as cidades que os comportam - e terem centralmente um sentido comercial, necessitam de novas formas de multiplicação de seu alcance, de atingirem o maior número possível de participantes-expectadores - e não mais participantes-interagentes de fato, como no caso dos antigos rituais e festas ${ }^{9}-\mathrm{e}$ de minimizar a anestesia reinante. Esses novos objetivos só poderiam ser alcançados com os recursos advindos da mídia eletrônica.

Os meios eletrônicos passam, então, a compor a estrutura central dos megaeventos e essa composição acompanha suas características primeiras de "uma natureza lúdica vertiginosa" [documento eletrônico], conforme aponta Baitello Jr. no artigo supracitado, referindo-se ao conceito de vertigem de Roger Caillois.

Participação interativa é aqui entendida como interação de fato, uma situação na qual os dois lados (ou mais) que interagem possuem forças e autodeterminação, senão iguais, ao menos próximas, e não tão absolutamente díspares como no caso dos megaeventos. A vivência pressuposta na participação interativa se refere a "tomar parte em" e não somente à postura dos "participantes" dos eventos atuais, que são, de fato, expectadores-consumidores. Mesmo considerando que a expectação e 0 consumo também são ativos, sabemos que são completamente motivados e dirigidos pela máquina já estabelecida pela indústria cultural, o que implica em um quase total aniquilamento da autodeterminação e do direito de escolha centrado no trabalho consciente da reflexão. 
Os meios eletrônicos abrigam em sua natureza a possibilidade dessa intensidade e fragmentação que levam à vertigem, recursos amplamente utilizados pelos megaeventos por meio da introdução desses mesmos meios em seus formatos e estruturas centrais. São telões gigantescos que, inclusive, suprimem a presença do artista (que ironicamente está presente, mas não é 0 alvo dos olhares), com milhares de imagens em intenso e ininterrupto movimento, associadas à música e a outros recursos como iluminação e efeitos especiais dos mais diversos, que promovem, sem sombra de dúvida, a sensação de vertigem. É a materialização da vertigem mediática - os jogos de Ilinx - no espaço do evento, tentando ocupar o lugar das experiências de vertigem vividas nos rituais religiosos.

0 paralelo entre jogo e megaeventos não é inocente. Toda a teoria de Caillois (1986) baseia-se nas primeiras discussões de Johan Huizinga (2005), em sua obra Homo Ludens, de 1938, que pontua o jogo como um elemento fundamental da cultura, por suas características simbólicas, de realidade autônoma, de evasão e de caráter estético, características que, quando consideradas, incluem os eventos e megaeventos como uma forma de jogo.

Caillois (1986), por sua vez, e com base na obra de Huizinga, desenvolve o conceito de jogo e cria algumas categorias fundamentais para os mesmos, entre elas, a de Ilinx (jogos de vertigem), assim apresentada:
Os jogos de vertigem, Ilinx, reúnem as atividades que buscam a vertigem e consistem na intenção de destruir por um instante a estabilidade da percepção e infringir à consciência lúcida uma espécie de pânico voluptuoso. Em qualquer caso, trata-se de alcançar uma espécie de espasmo, de transe ou de aturdimento que provoca a aniquilação da realidade de forma brusca. (p. 58)

Essa vertigem absorvida pelo megaevento e apresentada como parte fundamental de sua natureza e de seu contexto vem atender à dinâmica anteriormente apresentada.

Em uma sociedade anestesiada e imunizada, sem vínculos consistentes, imersa em meios de incomunicação, a busca do vínculo e da experiência do gregarismo - que viabilizam a comunicação (todos fatores inerentes à condição humana) parece-nos uma tentativa de resiliência.

A criação dessa ambiência

superhiperestimuladora favorável à vertigem nos megaeventos objetiva vencer essa situação de imunização dos contatos. A vertigem seria uma solução para 0 vazio encontrado na sociedade de massa, da falta de contatos aprofundados, de vivências e experiências reais (ou seja, promotoras de uma espécie de religare).

No entanto, a mesma continua somente atendendo à dinâmica da própria estrutura das cidades, à dinâmica da cultura de massas instaurada no século XX. Nada de novo sob o sol. Esse processo, além de não promover experiências de fortalecimento do sentimento comum e de transcendência, acaba por gerar 
ainda mais carências, mais vazios, e aumenta, com isso, a própria necessidade de consumo desses mesmos produtos.

\section{A vertigem instrumentalizada}

0 caráter principal do megaevento está ligado à idéia de diversão e a toda a cultura do entretenimento, e apesar desse não se exatamente 0 foco do presente texto, vemos na contribuição de V. Flusser (2002) sobre o tema da diversão, uma contribuição relevante demais para dela prescindirmos. Vilém Flusser (documento eletrônico) coloca em seu artigo "Da Diversão"10 que um dos sintomas mais inquietantes da decadência da civilização tecnológica é sua busca de diversão e que a diversão é uma aversão ao universo, "a recusa ao verter"(p. 02), uma forma que revela o tédio e a angústia do universo instrumentalizado em que vivemos. Para apoiar sua afirmação, propõe algumas observações acerca de certos tipos de diversão, exame este que, paradigmaticamente, serve à análise dos megaeventos enquanto diversão.

De acordo com 0 autor, esses elementos divertem por algumas razões fundamentais: divertem a atenção daquilo que chamamos, normalmente, de "realidade"; convertem o homem de participante em expectador; e criam uma inócua fuga do tédio. Inócua porque, pela instrumentalização a que 0 nosso mundo se encontra submetido, essa diversão só se coloca de modo a criar mais instrumentos, integrando ainda mais o homem na engrenagem funcional, o que acaba por intensificar o tédio e a angústia. Intensificando as relações do homem com essa pseudo-diversão, de fato, serve-se somente aos propósitos da manutenção do contexto que alimenta a própria máquina intrumentalizadora.

A vertigem provocada pelos megaeventos, dessa forma, ao invés de ser uma situação promotora da antítese da anestesia, da imunização dos contatos, da incomunicação, serve exatamente para intensificar esses fenômenos. Gera uma carência, um vazio, uma constante busca por uma transcendência que de fato não pode ser alcançada ${ }^{11}$ por estes meios. Não pode ser alcançada porque a mesma coloca-se como objetivo, alvo de consumo, e não mais como consequência de um processo complexo de amplificação da consciência. Transforma-se, desse modo, em mais um elemento instrumentalizado, que serve à máquina de consumo e de criação de novas carências, alimentadas por mais vazio e inocuidade, e pela inexistência de sentidos e experiências mais profundos e significativos. Servindo à lógica do mercado e do consumo, da instrumentalização e de uma racionalização funcional, esse tipo de vertigem alimenta somente o mesmo processo que a gera.

Artigo originalmente publicado no Jornal 0 Estado de São Paulo e disponível para consulta em: <www.cisc.org.br>, área restrita a pesquisadores cadastrados. 


\section{Referências Bibliográficas}

BAITELLO JR, Norval. 0 animal que parou os relógios. São Paulo: Annablume, 1999.

Tempo lento e espaço nulo - mídia

primária, secundária e terciária. Disponível em: <www.cisc.org.br> Acesso em: 06 mar. 2005.

Os meios da incomunicação. São Paulo:

Annablumme - CISC, 2005a.

A era da iconofagia. São Paulo: Hacker

Editores, 2005b.

; GUIMARÃES L.; PAIERO D., OLIVERIA, J. E.

(orgs.). Os símbolos vivem mais que os homens. São

Paulo, Annablume, 2006.

BAUMAN, Zygmunt. Modernidade líquida. Rio de Janeiro: Jorge Zahar, 2001.

Comunidade. Rio de Janeiro: Jorge Zahar, 2003.

BENJAMIN, W. Charles Baudelaire - A lyric poet in the era of high capitalism. New York: Verso Books, 1997.

BERLO, David K. 0 processo de comunicação. São

Paulo: Martins Fontes, 1999.

BYSTRINA, Ivan. Semiotik der kultur. Alemanha, s/d.

CAILLOIS, Roger. Los juegos y los hombres. México:

Fondo de Cultura Económica, 1986.

CONTRERA, Malena Segura. 0 mito na mídia. São

Paulo: Anablume, 1996.

Mídia e pânico. São Paulo: Annablume, 2002.

Publicidade e cia. São Paulo: Pioneira, 2003.

DEBORD, Guy. A sociedade do espetáculo. Rio de

Janeiro: Contraponto, 1997.

ELIADE, Mircea. 0 sagrado e o profano. São Paulo:

Martins Fontes, 2001

FLUSSER, Vilém. Da diversão. São Paulo: Centro

Interdisciplinar de Semiótica da Cultura e da
Mídia. Disponível em: <www.cisc.org.br>. Acesso em: 05 jul. 2005.

Da religiosidade. São Paulo: Escrituras, 2002.

HUIZINGA, Johan. Homo ludens. São Paulo:

Perspectiva, 2005.

KAMPER, Dietmar. 0 medial - 0 virtual - 0

telemático. São Paulo: Centro Interdisciplinar de

Semiótica da Cultura e da Mídia. Disponível em: <www.cisc.org.br>. Acesso em: 05 jul. 2005.

Corpo. São Paulo: Centro Interdisciplinar

de Semiótica da Cultura e da Mídia. Disponível em: $<$ www.cisc.org.br>. Acesso em: 05 jul. 2005.

KANDLE, Denis. A história da psy trance. Disponível em: <http://www.newagepunk.com/tranzine/13/ historia_psy_trance.htm > Acesso em: 31 ago. 2006.

KLEIN, Alberto Carlos Augusto. Culto e mídia. 1999. Dissertação (Mestrado em Comunicação e Semiótica)Pontifícia Universidade Católica de São Paulo, São Paulo, 1999

LORENZ, Konrad. Os oito pecados mortais da civilização. Lisboa: Litoral, 1992.

MORIN, Edgar. Cultura de Massas no Século XX - Vol. I - Neurose. Rio de Janeiro: Forense Universitária, 1997. Introdução ao pensamento complexo. 2. ed. Lisboa: Instituto Piaget, 1995.

0 paradigma perdido: a natureza humana. Portugal: Publicações Europa-América, 1973.

MOR0, Marcela. Planejamento e organização de eventos: apostila de curso livre. Jundiaí: Senac, 2002.

PROSS, Harry. La violencia de los símbolos sociales. Barcelona: Anthropos, 1989.

SINGER, Ben. Modernidade, hiperestímulo e o início do sensacionalismo popular In: CHARNEY, Léo; SCHWARTZ, Vanessa R.. 0 cinema e a invenção da vida moderna. São Paulo: Cosac e Nayf, 2004. 
SOUZA, Cláudio Manoel Duarte, A cibermúsica, djing, tribos, e cibercultura. Disponível em: $<\mathrm{http}: / / \mathrm{www}$. facom.ufba.br/ciberpesquisa/txt_cla.htm> Acesso em: 29 ago. 2006.

TENAN, Ilka Paulete Svissero. Eventos. São Paulo: Aleph, 2002.

TODOROV, Tzvetan. A vida em comum. Campinas: Papirus, 1996.

TURNER, Victor, W. 0 processo ritual. Petrópolis, Vozes, 1974.

VARGAS, Herom. Música pop, espetáculo e mito: questões de tempo e espaço. Revista Comunicarte, Campinas, n. 25, v. 19, 2002.

VELHO, Otávio Guilherme (org.). 0 fenômeno urbano. Rio de Janeiro: Zahar, 1967.

VIRILIO, Paul. Velocidade e política. São Paulo: Estação Liberdade, 1996. 


\section{Mediatic vertigo in} huge music events

\section{El vértigo mediático en los megaeventos musicales}

\section{Abstract}

This article proposes a reflection on the broad media ostentation which causes vertigo in huge music events. This media ostentation prompts a profusion of fragmented visual and audio images in constant and intense movement which characterizes the environment of this kind of event. It also tries to better understand the nature of such big events, peculiar in urban cultures, as well as the enormous appeal they have among young audiences that look for large concentration of people and also an excess of such social situations.

\section{Keywords}

Media processes. Huge musical events. Vertigo. Youth culture.

\section{Resumen}

El artículo plantea una reflexión acerca de la presencia del amplio aparato mediático que genera el vértigo presente en los "megaeventos" musicales. Este aparato mediático promociona una profusión de imágenes visuales y auditivas fragmentadas y en constante e intenso movimiento, caracterizando el ambiente propio de los megaeventos. El texto se ocupa de comprender mejor la naturaleza "mega" de estos eventos propios de la cultura urbana, así como la gran seducción que ese carácter superlativo ejerce sobre el público juvenil que busca exactamente esa concentración masiva de personas en un mismo espacio y los excesos característicos de esa situación social.

\section{Palabras clave}

Procesos mediáticos. Megaeventos musicales. Vértigo. Cultura juvenil. 


\section{Expediente}

A revista E-Compós é a publicação científica em formato eletrônico da Associação Nacional dos Programas de Pós-Graduação em Comunicação (Compós). Lançada em 2004, tem como principal finalidade difundir a produção acadêmica de pesquisadores da área de Comunicação, inseridos em instituições do Brasil e do exterior.
E-COMPÓS I www.e-compos.org.br I E-ISSN 1808-2599

Revista da Associação Nacional dos Programas de Pós-Graduação em Comunicação. Brasília, v.11, n.1, jan./abr. 2008.

A identificação das edições, a partir de 2008, passa a ser volume anual com três números.

\section{CONSELHO EDITORIAL}

\section{Afonso Albuquerque}

Universidade Federal Fluminense, Brasil

Alberto Carlos Augusto Klein

Universidade Estadual de Londrina, Brasi

Alex Fernando Teixeira Primo

Universidade Federal do Rio Grande do Sul, Brasi

Alfredo Vizeu

Universidade Federal de Pernambuco, Brasil

Ana Carolina Damboriarena Escosteguy

Pontifícia Universidade Católica do Rio Grande do Sul, Brasil

Ana Silvia Lopes Davi Médola

Universidade Estadual Paulista, Brasil

André Luiz Martins Lemos

Universidade Federal da Bahia, Brasil

Ângela Freire Prysthon

Universidade Federal de Pernambuco, Brasil

Antônio Fausto Neto

Universidade do Vale do Rio dos Sinos, Brasil

Antonio Carlos Hohlfeldt

Pontifícia Universidade Católica do Rio Grande do Sul, Brasil

Arlindo Ribeiro Machado

Universidade de São Paulo, Brasil

César Geraldo Guimarães

Universidade Federal de Minas Gerais, Brasi

Cristiane Freitas Gutfreind

Pontifícia Universidade Católica do Rio Grande do Sul, Brasil

Denilson Lopes

Universidade Federal do Rio de Janeiro, Brasil

Eduardo Peñuela Cañizal

Universidade Paulista, Brasil

Erick Felinto de Oliveira

Universidade do Estado do Rio de Janeiro, Brasil

Francisco Menezes Martins

Universidade Tuiuti do Paraná, Brasil

Gelson Santana

Universidade Anhembi/Morumbi, Brasil

Hector Ospina

Universidad de Manizales, Colômbia

leda Tucherman

Universidade Federal do Rio de Janeiro, Brasil

Itania Maria Mota Gomes

Universidade Federal da Bahia, Brasil

Janice Caiafa

Universidade Federal do Rio de Janeiro, Brasil

Jeder Silveira Janotti Junior

Universidade Federal da Bahia, Brasil
John DH Downing

University of Texas at Austin, Estados Unidos

José Luiz Aidar Prado

Pontifícia Universidade Católica de São Paulo, Brasil

José Luiz Warren Jardim Gomes Braga

Universidade do Vale do Rio dos Sinos, Brasi

Juremir Machado da Silva

Pontifícia Universidade Católica do Rio Grande do Sul, Brasil

Lorraine Leu

University of Bristol, Grã-Bretanha

Luiz Claudio Martino

Universidade de Brasília, Brasil

Maria Immacolata Vassallo de Lopes

Universidade de São Paulo, Brasil

Maria Lucia Santaella

Pontifícia Universidade Católica de São Paulo, Brasil

Mauro Pereira Porto

Tulane University, Estados Unidos

Muniz Sodre de Araujo Cabral

Universidade Federal do Rio de Janeiro, Brasil

Nilda Aparecida Jacks

Universidade Federal do Rio Grande do Sul, Brasil

Paulo Roberto Gibaldi Vaz

Universidade Federal do Rio de Janeiro, Brasil

Renato Cordeiro Gomes

Pontifícia Universidade Católica do Rio de Janeiro, Brasil

Ronaldo George Helal

Universidade do Estado do Rio de Janeiro, Brasil

Rosana de Lima Soares

Universidade de São Paulo, Brasil

Rossana Reguillo

Instituto Tecnológico y de Estudios Superiores do Occidente, México

Rousiley Celi Moreira Maia

Universidade Federal de Minas Gerais, Brasil

Sebastião Carlos de Morais Squirra

Universidade Metodista de São Paulo, Brasil

Simone Maria Andrade Pereira de Sá

Universidade Federal Fluminense, Brasil

Suzete Venturelli

Universidade de Brasília, Brasil

Valério Cruz Brittos

Universidade do Vale do Rio dos Sinos, Brasil

Veneza Mayora Ronsini

Universidade Federal de Santa Maria, Brasil

Vera Regina Veiga França

Universidade Federal de Minas Gerais, Brasil

\section{COMISSÃO EDITORIAL}

Ana Gruszynski I Universidade Federal do Rio Grande do Sul, Brasil João Freire Filho I Universidade Federal do Rio de Janeiro, Brasil Rose Melo Rocha I Escola Superior de Propaganda e Marketing, Brasil

\section{CONSULTORES AD HOC}

Bianca Freire-Medeiros I Fundação Getulio Vargas, Brasil Josimey Costa da Silva I Universidade Federal do Rio Grande do Norte, Brasil Maria Conceição Golobovante I Pontifícia Universidade Católica de São Paulo, Brasil Marlyvan Moraes de Alencar I Centro Universitário SENAC-SP, Brasil Miriam de Souza Rossini I Universidade Federal do Rio Grande do Sul, Brasil Paulo Ribeiro I Pontifícia Universidade Católica do Rio de Janeiro, Brasil Rita Alves de Oliveira I Centro Universitário SENAC, Brasil

REVISÃO DE TEXTO E TRADUÇÃO I Everton Cardoso ASSISTÊNCIA EDITORIAL E EDITORAÇÃO ELETRÔNICA I Raquel Castedo
COMPóS I www.compos.org.br

Associação Nacional dos Programas de Pós-Graduação em Comunicação

Presidente

Erick Felinto de Oliveira

Universidade do Estado do Rio de Janeiro, Brasil erickfelinto@uol.com.br

Vice-presidente

Ana Silvia Lopes Davi Médola

Universidade Estadual Paulista, Brasil

asilvia@faac.unesp.br

Secretária-Geral

Denize Correa Araújo

Universidade Tuiuti do Paraná, Brasil

denizearaujo@hotmail.com 